\title{
Inacoin Cryptocurrency Analysis: An Islamic Law Perspective
}

\author{
Filka Catur Windiastuti ${ }^{1}$ and Fauzul Hanif Noor Athief ${ }^{2}$ \\ ${ }^{1}$ Faculty of Islamic Studies, Universitas Muhammadiyah \\ Surakarta \\ email: vilka.caturwindiastuti@gmail.com \\ ${ }^{2}$ Faculty of Islamic Studies, Universitas Muhammadiyah \\ Surakarta \\ email: fauzul.hanif@ums.ac.id
}

\begin{abstract}
The existence of money makes buying and selling activity easier than the barter system. However, the increasing globalization of the world economy demands speed accelaration, ease and security of financial transactions. The discovery of cryptocurrency provides solution for the current payment system which relies highly on the third party in conducting digital transactions. One of those cryptocurrency products is Inacoin which is originated from Indonesia. Because this cryptocurrency is a contemporary problem that cannot be concluded directly from the classical fiqh book, a thorough investigation is needed to obtain the validity of this money from Islamic perspective. This research is a qualitative research that uses multimethod of normative-empirical Islamic law perspective in discussing the aforementioned problem. This study concluded that the existence of Inacoin cannot be accepted as money since there are Islamic requirements or criteria that are not met. In addition, the use of Inacoin is mostly for trading commodity, not as money. The Inacoin trade is legitimate but unlawful, because Inacoin has fulfilled the pillars and requirements of the Al-Sarf, yet contradicted some Islamic principal such as maisir, gharar, and possibility of harming its user
\end{abstract}

Keywords: Inacoin, Cryptocurrency, Al-Șarf 


\section{INTRODUCTION}

The history of commerce notes that humans used various means to survive in fulfilling their day to day needs. At the level of civilization which is still simple, humans use barter system. Along with the development in human society, it was found that transacting using barter system is difficult due to an increase many complex problems. With the existence of these problems, there arose a thought that provides an alternative means of exchange which facilitates buying and selling and can be accepted by society, namely money.

The existence of money makes buying and selling transactions easier from the barter system. However, the increasing globalization of the world economy has resulted in the increasing need for speed, convenience and security of financial transactions. This makes paper money has many limitations in meeting human needs. Bank Indonesia as the payment system authority in Indonesia divides two types of payment system instruments, namely cash and non-cash (Mulyanto, 2015). Cash payment instruments are in the form of paper money while non-cash payments use cards, checks, banknotes, debit notes, and electronic money. In this regard, it is important to note that payments using non-cash is favorable for public in making their transactions nowadays.

The development of money from time to time shows the existence of an increasingly advanced civilization in science and technology. One of them is the emergence of the invention of cryptocurrency as an answer to the constraints faced by the current payment system that relies heavily on third party as a trusted payment product developer to manage digital transactions. Cryptocurrency is the name given to a system that uses cryptography to securely transmit data and to process the exchange of digital tokens (Mulyanto, 2015).

At the end of 2008 there was a programmer who claimed to be called as Satoshi Nakamoto (pseudonym) to create a new digital currency named Bitcoin (Mulyanto, 2015). Bitcoin's fame has steadily accelerated since its introduction in early 2009, reaching a price of more than Rp200 million per coin. The success 
of Bitcoin was followed by the emergence of the cryptocurrency industry which now has more than 1.000 products sold in various cryptocurrency markets throughout the world (Wijaya, 2018).

Those thousands of type of cryptocurrency come one after another. Each of it tries to overcome the shortcoming found in Bitcoin and any other cryptocurrency. Based on the intense and wide usage of cryptocurrency, along with the shortcoming from every type of cryptocurrencies, a community in Indonesia introduced new type of it called Inacoin. This cryptocurrency is purely made by the hand of Indonesian people which follows the system applied by Bitcoin. Inacoin crypto was founded by Iwan Kurniawan who has been working in the networking field and founder of an MLM company. He combined the concept of networking and cryptocurrency which was launched in July 2018.

People in Indonesia starts to pursue Inacoin which price is still affordable compared to Bitcoin which already reached million Rupiah per coin. Those who try to buy Incation is in the hope that in the future Inacoin prices will compete against Bitcoin. Therefore, one of the members' goals is to buy Inacoin when prices are low and resell it when the prices skyrocket and hit its peak.

Buying and selling in the view of Al-Qur'an, As-Sunnah and Ijma is permissible. In addition, all scholars agree on its permissibility. The sale and purchase of foreign exchange of any currencies is known as al-șarf contract in Islam. All scholars fully agree on the permissibility of al-sarf as it has been practiced by people since the time of the Prophet up until today without objections from anyone (ISRA, 2015). In definition, Al-Sarf is the sale of money to get money which is analogous to the principle of the gold and silver exchange which must be done in cash to avoid ribawi transactions as it is narrated from Prophet in his Hadith (Al-Mundziri, 2002).

The most important function of money is as unit of account and medium of exchange. However, depending on what is being used as money, money can also function as a store of value (ISRA, 2015). To be able to function as money, it must fulfill several requirements. The purpose of the requirements is that once it 
is as considered money, it is acceptable by all levels of society and thus can be used as a medium of exchange by the owner. As mentioned in the purpose of the requirements, we can infere several criteria as the standard requirement (Kasmir, 2002). These criteria include guarantees, common acceptability, stable value, easy storage, easy to carriage, not easily damaged, easily divided, and an elastic supply.

Sharia is the cornerstone of the Islamic worldview which is used as a source of knowledge that provides the basis for the system and operation of Islamic finance. It also serves as the guidance in facing countless change within society throughout the time (Kasmir, 2002). The foundation or legal basis of Islamic worldview sourced from the Qur'an, al-hadith, ijma', and qiyas. Apart from it, it is also important to mention that rules and regulation diverse from every jurisdiction. Thus in case of Indonesia, the positive law also serves as the additional basis of the law (Marzuki, 2017).

Regulation in Indonesia regarding the use of cryptocurrency still faces many pros and cons. This is because this currency does not meet the elements and criteria of money in Indonesia. Bank Indonesia has also issued a circular letter through its press media on February 16, 2014:

"Bitcoin and other virtual currencies are not legal currencies or payment instruments in Indonesia. People are encouraged to be careful of Bitcoin and other virtual currencies. All risks related to ownership / use of Bitcoin are borne by the owner / user of Bitcoin and other virtual currencies." (Bank Indonesia press release no. 16/6/Dkom).

Based on the background of the aforementioned problem, we are interested in examining this problem and analyzing it from an Islamic perspective. Therefore, the author conducted a research in a thesis entitled: Inacoin Cryptocurrency Analysis: An Islamic Law Perspective 


\section{LITERATURE REVIEW}

Research on money in the viewpoint of Islam and positive law has indeed been done a lot. However, the research of the Inacoin currency which was created by Iwan Kurniawan from Indonesia and launched on July 2018 is still vacuum from any research. Thus, no one has carried out research on what the Inacoin currency is from Islamic perspective. Nevertheless, there are some studies that are relevant to the topic of our interest here.

First, it is important to us to know that there are types of money circulated nowadays. This classification is based on the purpose of its use in accordance with the needs of various parties. The types of money evolve according to the the times whether the evolution occurs in its intrinsic value, nominal value or the function of money itself (Kasmir, 2002).

The first one is the commodity money which is seen as the oldest form of money. It was used during the barter system age (Hasan, 2004). Second is the fiat money which was created out of paper or metal with lower price so that this money can have higher value than its intrinsic value. The third is Giral which is a form of bank's money. It can only be used for transactions by check (demand deposit). However, not all people want to accept it because it is not perfectly liquid unless the first two money. Fourth, we have near money which is almost perfectly liquid. Thus, it is a type of money that must be disbursed or exchanged first before it can be used. The example of this type of money is ATM cards, Credit Cards, Deposits, and savings books (Murni, 2006). Fifth is the electronic or digital money which is circulated through digital transactions. Usually, these transactions involve the use of computer networks (such as the internet and digital price storage systems). The last is virtual currency which is a digital money issued by parties other than monetary authority. This type of money is obtained by purchasing, transferring (reward), or mining (the process of producing a number of new virtual currencies, involving complicated mathematical processes). This digital money is issued or controlled by the developer of a community and is used and accepted by members of that virtual community (Bank Indonesia press release no. 20/4/Dkom). 
Since this research focuses only on the virtual currency, we will deliver the previous studies on that topic only. The discussion of any other type of money will not be included since it is outside the range of our study here. We have documented some of the studies on virtual currency that can be seen in the next paragraph.

First is the research conducted by (Mulyanto, 2015) entitled "Utilization of Cryptocurrency as the Application of the Rupiah in the Digital Form Using Bitcoin Technology". The type of research is qualitative research and narrative analysis methods with sources of data from various media publications. The results of the study stated that Bitcoin cryptocurrency is a relatively new technology and needs further study. There is no standardization of payment system protocols in Indonesia, making third parties (banks and non-banks) create their respective payment infrastructure. After conducting an electronic currency study in Indonesia, the results of a comparison were made between electronic money technology that uses store value and product access with electronic money that uses Bitcoin technology. Several assessment criteria were obtained from the result. If Bitcoin technology is implemented, it can be possible to combine computing resources (banks and nonbanks) to create a decentralized peer-to-peer network so that providers have a shared access data system. The impact for the community is enough to have one type of electronic money both in physical and digital form so that it can be recognized by various reading terminals from each service provider.

There was also another study conducted by Che Ludin et al., (2014) which concluded that Bitcoin has not been accepted as a legitimate currency from Islamic perspective because its value is still unstable. Using the maqasid shariah approach of maslahah and mafsadah, there is still no need for the use of Bitcoin in Malaysia. It is also found that there is no need for daruriyyat, häjiyyat and tahsiniyyat. It also still possesses high risk because of the potential to conduct illegal trading activities. Malaysia is not yet willing to do Bitcoin sale and purchase due to the the low level of people's knowledge on Bitcoin. Besides it requires additional regulation certainty to ensure that every user gets guaranteed safety and thus the transaction can be watched over. 
Another study is done by Sholihah (2014) in a bachelor thesis entitled "Overview of Islamic Law on Bitcoin Digital Money with Studies on DSN-MUI and Artabit Companies". In this thesis, the author uses qualitative-descriptive research method. It is said in the result of the thesis that Bitcoin-based money exchange mechanism at Arbit Company is done by filling in the form on the website that continued by following the next instructions. In addition, in the review of fiqh muamalah through studies on DSN-MUI, it was stated that Bitcoin-based money exchange transactions cannot be said to be legitimate money exchange transactions in Islam. Apart from Bitcoin has no legality from the government, it also does not fulfill the requirements as a currency in both conventional and economic economics. Here, Bitcoin is prone to fraud.

\section{METHODOLOGY}

This study uses qualitative approach since this type of approach helps to produce in-depth descriptions of the behavior that can be observed in the Inacoin group from a comprehensive and holistic perspective (Sujarweni, 2014). Since the main purpose of the discussion in this paper is the study of law, the author uses multi methods in the form of empirical normative Islamic law model. The model in normative legal research is intended to be the foundation as starting basis for researcher's framework of thinking and conducting the analysis (Fajar nd and Achmad, 2015). In addition, the empirical legal research is legal research taken from facts that exist in a society, legal entity or government agency.

There are two types of data used in this study, namely primary and secondary. The source of primary data is obtained from the results of interviews with the Inacoin community, data collection through www.indoco.io and www.indoco.co.id and data provided by the community. The secondary data in this study is obtained from literature studies, journals, papers, media in the form of writings, videos and sound recordings related to Inacoin. Interview techniques are deliberately used for data collection because the technique helps to find out things from respondents in 
more in-depth manner while having small number of respondents (Sugiyono, 2010). The form of interview conducted is an unstructured interview addressed to the Inacoin community where the questions arevery open and uncontrolled. This interview aims to find out updated information about Inacoin..

In addition, researchers also used observation techniques in the form of non-participatory observations where researchers were not involved and stood only as independent observers (Sugiyono, 2010). Therefore, the researcher only became an observer of the Inacoin community in the Whatsapp group INACOIN TEAM. The authors created Inacoin and Indoco Exchanger accounts as well to help understand more about how Inacoin works. During the observation for the research, authors tried to be natural so that not seen as doing research. The target of this observation is the Inacoin trading website www.indoco.io and www.indoco.co.id.

Furthermore, the analysis will be carried out using deductive logic that departs from the general facts of Inacoin and the legal theory that relates to it which in the end providing the conclusions obtained (Yusuf, 2014). The presentation of the results of the analysis will be carried out using a descriptive data model.

\section{RESULT AND FINDING}

Cryptocurrency is a decentralized digital currency and is managed by a peer-to-peer technology network. The implementation depends on the principles of cryptography to validate transactions and the generation of the currency itself. In the other word, it can be called as a form of currency based on calculations or mathematics. Unlike paper currency or printed metal coins, cryptocurrency is produced by solving mathematical problems based on cryptography.

The Blockchain is a transaction recording technology integrated with modern technology, which has a unique, irreversible (eternal) code that revolutionizes the workings of the internet, banking and other things (Inacoin, 2018). Blockchain is like a big book where all transactions are transparent and can be checked by everyone to ensure its credibility. 
Inacoin is a new breakthrough in the world of cryptocurrency in Indonesia as a work of the Indonesian people in the field of financial technology (fintech) using blockchain technology. It is, as said, developed for the purpose of advancing the national creative economy, especially the MSME sector to create new entrepreneurs in all fields by utilizing the latest technology like cryptocurrency and blockchain. Inacoin has a vision to develop creative economy and to bring Indonesian cryptocurrency into the future by utilizing blockchain technology. Inacoin also has a mission for being a very safe, decentralized digital asset and cannot be influenced by anyone or other countries.

Inacoin was founded by Iwan Kurniawan, an Indonesian nationality who since 1990 has been working in the field of netweok and society. He also established MLM companies in Indonesia. By following the development of cryptocurrency, he combined the concept of networking and cryptocurrency to present Inacoin and the Cryptocurrency Exchanger. Inacoin introduced in April 2018 and afterward in July 2018 Inacoin and Indoco Exchangers were inaugurated. The grand launching of Inacoin was held on March 31, 2019 and in accordance with their launding of Ina Academy.

Inacoin only has $18,000,000$ coins in supply. 5 coins is given for free for the first 60,000 registrants. The remaining 17,700,000 are for stacking, networking and mining programs. Inacoin can be mined for the next 200 years.

Table 1. Inacoin Specification

\begin{tabular}{ll}
\hline \multicolumn{1}{c}{ Name } & \multicolumn{1}{c}{ Inacoin } \\
\hline Transaction Code & INA \\
Algoritm & X11 \\
Blockchain & POW/POS \\
Total Supply & $18,000,000$ \\
Stacking dan Networking & $6,300,000$ \\
Free Coin INA & 300,000 \\
Mining & $11,400,000$ \\
\hline
\end{tabular}

Source: Self-documentation 


\section{Main Concept of Inacoin}

\section{Networking}

Networking is a referral network built by an upline. Referral itself means anyone who is invited and agreed to join the Inacoin network based on a reference called upline. Upon a deposit of a referral, the upline as network creator will get $10-30 \%$ of the deposit amount the referrals do provided the user who registers uses an upline referral link must participate in the program provided (Inacoin, 2018). However, after the stacking program is complete, this $10-30 \%$ bonus is no longer valid. Currently networking bonus is $6-15 \%$ of the amount of deposits that referrals do.

Figure 1: Project Networking

\begin{tabular}{|c|c|}
\hline \multicolumn{3}{|c|}{ PROJECT NETWORKING } \\
REFFERAL \\
MEMBER \\
\hline Level 1 & $6 \%$ \\
\hline Level 2 & $1 \%$ \\
\hline Level 3 & $1 \%$ \\
\hline Level 4 & $1 \%$ \\
\hline Level 5 & $1 \%$ \\
\hline Level 6 & $1 \%$ \\
\hline Level 7 & $1 \%$ \\
\hline Level 8 & $1 \%$ \\
\hline Level 9 & $1 \%$ \\
\hline Level 10 & $1 \%$ \\
\hline
\end{tabular}

Source: Inacoin (2018) 


\section{Stacking}

Stacking is storing and holding coins in a virtual wallet, so that an active member can get up to $120 \%$ annual return depending on type of the coin (Inacoin, 2018).

\section{Figure 2: Stacking Project Management}

\begin{tabular}{|c|c|c|c|}
\hline \multicolumn{4}{|c|}{$\begin{array}{c}\text { STACKING PROJECT MANAGEMENT } \\
\text { Project Stacking Amount By Inacoin, on Juni } 2018 \text { - Closed } \\
\text { December } 2018\end{array}$} \\
\hline Paket & Total Coin & Coin Value & ROI/DAILY \\
\hline Silver & $50-1000$ & INACONN & $0,75 \%$ \\
\hline Gold & $1001-5000$ & INACOIN & $1,0 \%$ \\
\hline Platinum & $5001-\mathrm{dst}$ & INACONN & $1,25 \%$ \\
\hline \multicolumn{4}{|c|}{$\begin{array}{l}\text { Note: } \\
\text { - ROI is paid in the form of Inacoin } \\
\text { - Stacking project contract is } 180 \text { days. } \\
\text { - The purchase of Inacoin can be done using Bitcoin or } \\
\text { Etherium. }\end{array}$} \\
\hline
\end{tabular}

Source: Inacoin (2018)

Figure 3: Project Stacking

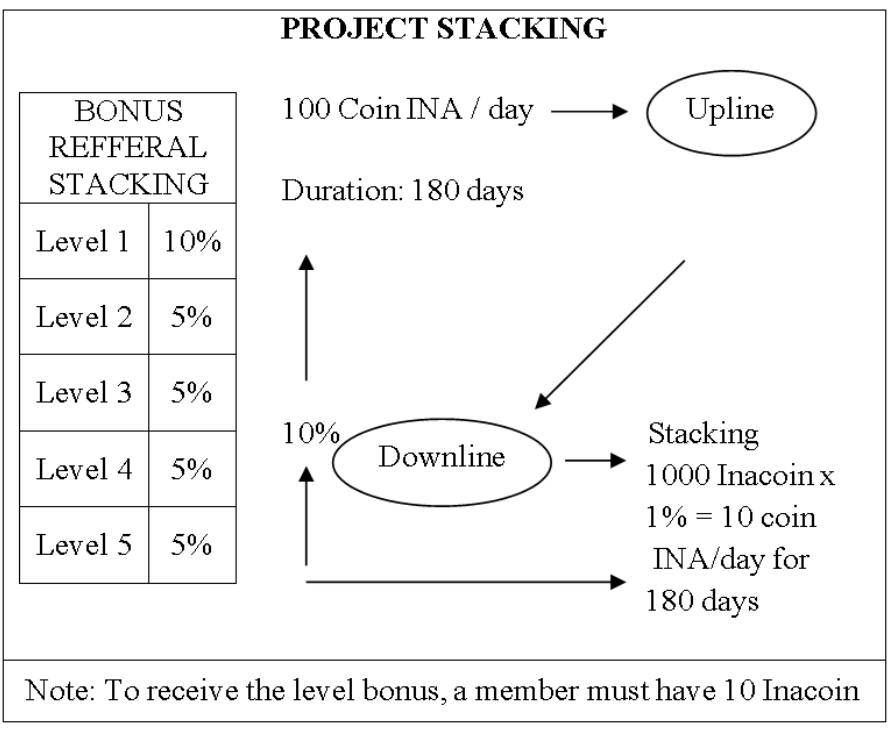

Source: Inacoin (2018) 


\section{Mining}

Mining is a process of producing new coin of Inacoin or any cryptocurrency through operations from combining special software, mining equipment, and PCs. The term miining can also be defined as an attempt to break new blocks by solving algorithms. In this way, a new coin will be obtained and ready to be transacted. Of course this requires huge costs and enormous time during coin mining process (Inacoin, 2018).

Mining in Inacoin is done by companies using their Mining Farm or could be done privately by individual if they have the mining tools. Since the mining tools and mining processes requires a lot of costs, the company provides mining programs with Inacoin orders on the www.inacoin.io account. The minimum order to join the mining program is 1 Lot (20 Inacoin) and it applies to a maximum of 50 Lot $=1000$ Inacoin. ${ }^{1}$

1 Interview with Andri Putra, a member of Inacoin community 
Figure 4: Project Mining

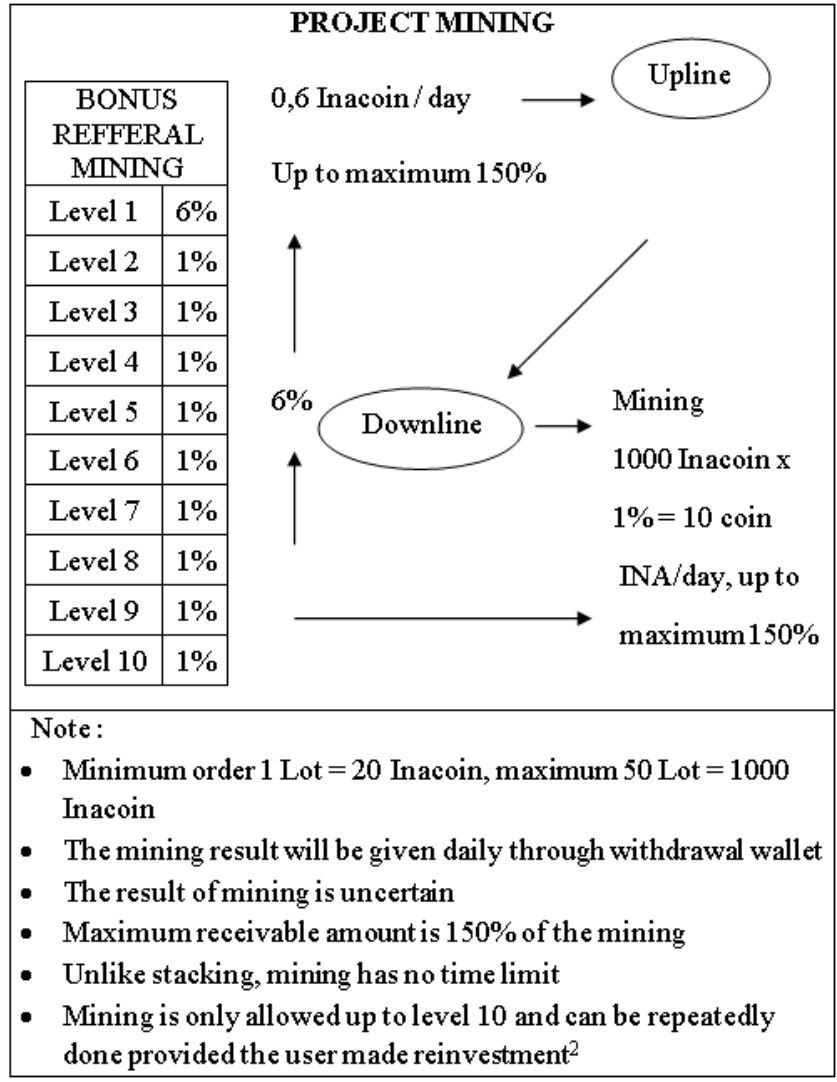

Source: Inacoin (2018)

\section{Trading}

Trading is the activity of exchanging goods or services or both based on an agreement between two parties (seller and buyer) rather than coercion. Crypto trading is a digital coin trading. Trading always has two components, namely profit and loss (Inacoin, 2018). Trade activity here requires a service provider or exchanger. Exchanger is a provider of crypto trading services or meeting place for crypto buyers and sellers where the law of supply and demand is applied.

The four points mentioned above are the basic concept of how Inacoin network works. Apart from those four, basically the what excites most for the user of Inacoin is the trading acitvity. 
Trading activity in digital world is not much different from buying and selling that exists in the real world which involves presence of sellers, buyers, objects traded and form of the contract. However, what differs between those two world is means and model of transaction. In the real world the transaction model used is face to face between sellers and buyers. Thus, it is different from transaction model that exists in cyberspace where most people make a transaction such as buying and selling without knowing the condition or existence of the object being traded.

Based on observations in the Inacoin community whatsapp group, thing that often occur in the Inacoin trade is the use of fluctuations in Inacoin values which is then exploited as the reason behind the trading. The fluctuation actually attracts people to do more speculation.. The price of one Inacoin at the commencement of the trading platform in July 2018 was only Rp. 15,000. On March 2019 the price already became Rp.463,000. This opens a great opportunity for users to benefit from Inacoin trading.

Table 2. Price Record of Inacoin July 2018 - March 2019

\begin{tabular}{lc}
\hline \multicolumn{1}{c}{ Month } & Price \\
\hline 24 July 2018 & Rp. 15.000 \\
August 2018 & Rp. 97.000 \\
September 2018 & Rp. 131.000 \\
October 2018 & Rp. 176.000 \\
November 2018 & Rp. 349.000 \\
December 2018 & Rp. 368.000 \\
January 2019 & Rp. 394.000 \\
February 2019 & Rp. 408.612 \\
March 2019 & Rp. 463.000 \\
\hline
\end{tabular}

Source: indoco.io.id

If someone buys Inacoin in July when the price was still Rp. 15,000 with a minimum purchase of 10 Inacoin as a condition of Inacoin, then Rp. 15,000 x 10 is Rp. 150,000. Then someone resells Inacoin in March 2019 when the price per Inacoin is Rp. 463,000 means that the person has made a profit of Rp. 4,480,000 in approximately 8 months. This advantage can be gained by only 
using trading activity. However, if someone takes part in other program provided such as networking, stacking or mining, then that person absolutely will get more benefits.

According to an explanation from the Inacoin community activist Shiwa Hadi on April 4, 2019 through Whatsapp, the Grand Launching of Inawallet was held on March 31, 2019. It is the all-in-one application which will have several menus which are:

1. Inacoin pawnshop. This app is used when Inacoin stakeholders suddenly need money. In this case, there is no need to sell the coin. They might pawn the coin they own through Inawallet so that when the coin experiences an increase in price it does not suffer a loss. The disbursement of the pawn will range from $70 \%$ to $80 \%$ of total Inacoin assets that person own. Minimum credit is 5 million with unlimited maximum.

2. PPOB (Payment Point Online Bank). This app is used for online payments such as payment of electricity bill, water bill, motorbike loans, and other payments.

3. Payment Gateway. All stakeholders of Inacoin can make payments through Inawallet to merchants who work with Inacoin.

However, this program still cannot be used, because it still waits regulation from the OJK (Financial Services Authority). Shiwa Hadi also stated that Inacoin cryptocurrency has been recognized by BAPPEPTI (Commodity Futures Trading Regulatory Agency). This was proven by the presence of Ministry of Trade Act No. 99/2018 which states that all types of crypto assets are legally traded in Indonesia as commodities that can be used as Futures Contract Subjects and can be traded on the Future Exchange.

\section{Analysis of Inacoin Existence as Virtual Currency}

In meeting the needs or carrying out economic activities, human beings need tools as payments called money. The fulfillment of the need to use the money makes money have a function. However, the money does not provide a direct function. 
In the other word, when money is used to buy goods, it is the item purchased that will provide utility, not the money itself (Hasan, 2004).

In Islamic economics the most important function of money is to provide usage as a unit of account and medium of exchange. However, depending on what is being used as money, money can also function as a store of value (ISRA, 2015). To make money can be used as its function and accepted by all levels of society, it is necessary to know some of the requirements and criteria that must be fulfilled for a thing to be regarded as money.

First: the availability of guarantee. It is important to note that in nowadays transacation, every money issued by certain country must be backed and guaranteed by that country as its issuer. Thus, the guarantee is in the form of back up regulation to help ensuring its acceptability among society. However, we find no regulation regarding Inacoin currently. Inacoin members only rely on Government Regulation No. 99 of 2018 concerning General Policy for the Implementation of Crypto Asset Futures Trading. However, this regulation does not mention the meaning of Crypto Assets nor the cryptocurrency word within it.

On the other hand, on January 13, 2018 Bank Indonesia conducted a question and answer session in its press release about the notion of virtual currency. In that press release, it mentioned that virtual currency is digital money issued by parties other than monetary authority obtained by means of purchases, transfers, or mining (i.e. a process of generating new virtual currencies through the means of complicated mathematical processes). This digital money is issued / controlled by the developer community and is used and accepted by members of the virtual community (Bank Indonesia press release no. 20/4/Dkom). From this press release, we can understand that Inacoin falls under this notion.

In addition, Bank Indonesia continued its statement to the public, which was conveyed through its press release on February 16, 2014. This statement also has been delivered many times by BI to the public. Bank Indonesia read: 
"Pertaining to Law No.7 of 2011 on Currencies and Law No. 231999 which was later amended several times, most recently by Law No.6 of 2009, Bitcoin and other virtual currencies are not legal currencies or payment instruments in Indonesia. People are encouraged to be careful of Bitcoin and other virtual currencies. All risks related to ownership / use of Bitcoin are borne by the owner / user of Bitcoin and other virtual currencies." (Bank Indonesia press release no. 16/6/Dkom).

The press release underlines two things. First, Bitcoin and other virtual currencies are not considered as legitimate money in Indonesia. Second, the risk of cryptocurrency circulation is borne by each individual. However, it is not clearly mentioned in the statement about prohibition of virtual currency and its punishment as consequences that will be borne by cryptocurrency users. Meanwhile, it is stated in article 33 No. 7 of 2011:

"As referred to in article 21 paragraph (1) shall be punished with imprisonment at most, a 1 (one) year and a fine of a maximum of Rp. 200,000,000.00 (two hundred million rupiahs)"'.

In the meantime, OJK in its press release stated that the application of digital currencies still needs further study. As we can see here, there is disagreement in this case between government institutions which are BAPPEBTI, BI and the OJK. Those institutions have not synchronized cerain legal basis for the virtual currency to the public. However, with regard to this cryptocurrency, it is refers more to the policies introduced by BI and OJK since these two body has more authority for the monetary system in Indonesia.

Second: publicly acceptable. It means that the money must be generally accepted by the public so that the money might carry out its functions. Inacoin is still running nowaday and is used by some people until they become the member of 
Inacoin users. Regarding this matter, there is a maxim says ماستعمله الناس حجة يجب العمل بها (what many people usually practice is hujjah which must be practiced). However, it must be noticed that some people cannot accept Inacoin. Meanwhile, this rule only applies if all countries agree that Inacoin can be used as a currency.

Third: stable value. Money must have stable and determined value which allows only small fluctuation. In reality, Inacoin prices experience price changes from time to time which expose its user into high risk of loss. In the same time, PT Indoco Solusi Pratama (as the company issuing Inacoin) is not responsible for changes in fluctuations in Inacoin exchange rate.

Fourth: money must be easily stored in various places including in small space yet having large quantities. This means that money must have flexibility. Regarding this criterion, any amount of Inacoin is easily stored because it is only a digital form that can be stored via e-wallet on a PC, smartphone or tablet.

Fifth: easy to carry. Inacoin is indeed has no physical form. However, since Inacoin is stored in e-wallet, Inacoin can be accessed anywhere and anytime as long as it is connected with internet access via PC, smartphone or tablet.

Sixth: not easily damaged. When we try to compare between prevailing rupiah currency with Inacoin virtual currency, Inacoin seems to be more durable. However, both types of currency can be damaged. Rupiah money can be damaged by tearing while Inacoin can suffer damages from lossing due to viruses, spam, or piracy.

Seventh: easy to share. It means that money must be easily divided into smaller unit. Inacoin exists in the digital form which amount is difficult to break down into smaller unit.

Eight: supply must be elastic. The amount of available money must be sufficient for current conditions with no excess or shortage. Meanwhile, the supply of Inacoin is only 18 million. On the other hand, the number of Inacoin members has increased. With the limited supply, Inacoin members and its users will face difficulty in using this cryptocurrency. 
Ninth: the concept of money in Islamic economics is different from the concept of money in conventional economics. In Islamic economics, the concept of money strongly states that money is money, money is not capital. Conversely, the concept of money in a conventional economy is often interpreted falsely. Sometimes, money is considered as money and sometimes it is also considered as capital (Karim, 2007). Here, Inacoin can be used as money for payments as well as can be stored to serve as regular commodity.

According to Al-Ghazali in his book Ihya Ulumuddin, money functions as a medium of exchange, but money is not desired for the money itself. In short, Al-Ghazali points out that money is created to facilitate exchange and establish the fair value of the exchange while emphasizing that money is not a commodity (Hasan, 2004). In reality, Inacoin members make Inacoin as a digital commodity or asset.

From the analysis described above, the researcher draws the conclusion that the existence of Inacoin cannot be called a currency, because it does not fulfill most of the terms or criteria for a thing to be considered as money. The function of Inacoin is also not in accordance with the function of money in the Islamic economy. This is because Inacoin serves as the commodity traded in most of the time, not as a medium of exchange.

\section{Inacoin transaction from Islamic Perspective}

The development of science and technology from time to time shows the existence of an increasingly advanced civilization. Inacoin is one part of this development. Inacoin uses cryptography where its value refers to the power of supply and demand. Anybody who wants to own and use Inacoin must have a virtual wallet where it can function to receive or send Inacoin to other people as well as any financial transaction. Inacoin's sell and purchase services is held by Indoco Exchager at the site address www.indoco.co.id.

If we try to see the trading scheme within Inacoin, we can understand that it is similar to al-sarf transaction. Technically, bay' al-șarf is the sale of money for money. This transaction is permissible in Islam as long as it fulfills the required pillars and 
conditions mentioned in Qur'an, hadith, as well as ijma The basis of its permissibilty lays on surah An-Nisa verse 29 read:

"O you who have believed, do not consume one another's wealth unjustly but only [in lawful] business by mutual consent. And do not kill yourselves [or one another]. Indeed, Allah is to you ever Merciful"

There is also another verse in Qur'an chapter Al-Baqarah verse 275 related to this matter which read:

"...But Allah has permitted trade and has forbidden interest. So whoever has received an admonition from his Lord and desists may have what is past, and his affair rests with Allah . But whoever returns to [dealing in interest or usury] - those are the companions of the Fire; they will abide eternally therein."

Apart from it, there are some fatwa that has been produced regarding the permissibility of al-șarf in the form of digity currency. The fatwa are as below:

Fatwa No. 219328:

"Electronic money is the money circulated in the digital world. This type of money even though has no similar shape with the rest of money, it has similarity in term of its substance. Thus, such electronic money takes the ruling of the currency in which its value is stored. ${ }^{2}$

Fatwa Syabakah Islamiyah No. 191641

"Digital currency or electronic money is a currency in electronic form other than paper or metal. Therefore, buying it using different currency is considered as al-șarf."

2 https://islamqa.info/ar/answers/ ما_حكم_النقود_الالكترونية accessed on 23 February 2019. 
Fatwa Syabakah Islamiyah Nomor 251170

"Whoever posesses any of that electronic money through a lawful means, then there is no harm for that person to use it in permissible activities."

The aforementioned two verses are used as a guideline by Muslims in doing al-sarf transactions. As it is mentioned in the verses, Allah justifies trading on the basis of mutual consent while Allah forbids usury and prohibits taking property from others in a vanity way. Besides that, from three fatwa mentioned earlier, we can conclude that the sale and purchase of digital currency has same ruling with al-sarf as long as it is used in permissible way. Furthermore, to find out whether or not Inacoin is valid, it is necessary to refer to pillars, terms and ruling on al-șarf. There are several pillars of al-șarf which must be fulfilled. If one of these pillars is not met, the contract becomes fāsid or void. The pillars include:

1. Parties involved in contract: the buyer and seller (Ascarya, 2012). In Inacoin, the sellers are member who sells Inacoin in exchange of Rupiah currency. Meanwhile, the buyers are member of Inacoin community who purchases Inacoin with rupiah.

2. Subject matter: the object intended to get exchanged and the exchange price (Ascarya, 2012). In Inacoin the object is the Inacoin itself while the exchange price is money in form of rupiah currency. In terms of object which is traded, Inacoin can be handed over from the seller to the buyer in non physical form. However, if any of the parties requested its physical form, then they will find nothing.

3. Sighah: the offer and acceptance. Offer means statement delivered at the initial of contract time. Acceptance (qabul) is an express of agreement for receiving the offer from another party in a contract (Ascarya, 2012). In this Inacoin sale and purchase transaction, the sighah delivered through the 
online contract is in principle has same character with other agreement in general. Since it can only be done within an online system, the contracting parties cannot communicate in one and same place (majlis). However, the parties can directly communicate through the means of electronic devices connected to the internet. In this transaction, the identity of the buyer is unknown.

Apart from the pillars, there are conditions of al-sarf that must be fulfilled. The conditions are as follow:

1. Each party must possess the ownership before leaving apart. This is to avoid riba nasi'ah (deferment type of riba).

2. Transactions must be done under equal value for some types of commodities. This is to avoid the change of contract substance towards kāli bil kāli transaction (sale and purchase of debt with another debt) which leads into riba fadhl.

3. Free from khiyar al-shart. This is to prevent actual procurement or completion of ownership transfer (ISRA, 2015).

4. Non deferred payment (must be done in cash).

Based from the explanation above, Inacoin can fulfill the pillars and the terms of al-sarf. However, there is another requirement that must be fulfilled emerges from majority opinion of contemporary moslem scholars. This opinion can be found in Fatwa of the National Sharia Council No. 28 / DSN-MUI / III / 2002 concerning Sale and Purchase of Currency (Al-Sarf). This fatwa contains provisions the exchange is not meant for speculation purpose. In addition, sale and purchase for different types of currencies must be done under the prevailing exchange rate in the time the transaction is done.

Currently, trading transactions that occur in Inacoin are more often used for speculation by the mean of purchasing Inacoin in order to take advantage of price fluctuations through commonly understood method which is buy at low prices and sell at high 
prices. In addition, Inacoin is also not only considered as a virtual currency, but is also used as a commodity that can be invested while the underlying investment is not clear.

Maqāsid shariah from the issuance of money is to help easing our life. To fulfill that, money must have legal force and existence. Unfortunately, since the value of Inacoin is not guaranteed and even the government does not guarantee its existence, then this cryptocurrency will be prone to fraud. On the other hand, Inacoin is only stored on computers or smartphones, where it is prone to damage due to viruses, and theft by hackers. Unstable price fluctuations are also feared as a means of money game. Therefore, the existence of Inacoin is in the contrary with maqāssid shariah since there is a fear that this Inacoin will collapse due to lack of maintenance for its system.

In this case, if we try to analyze it through legal maxim of fiqh which says that harmful thing must be removed, then Inacoin has that harmful characteristic which renders its existence in a whole must be avoided. This fiqh rule is based on the hadith narrated by Ibnu Majah read, "no harm and causing harm is allowed."

Majority of moslem scholars agrees that the wisdom of prescribing laws to humans is to achieve benefits and reject harm. Imam Ghazali asserted that the sentence of prescription of law is not to achieve human desire and interests, but on the contrary is to maintain the Five Sharia Goals (kulliyāt al-khamsah) which is to maintain religion, soul, mind, wealth and offspring (Che Ludin, 2014).

The development of science and human needs becomes increasingly complex which makes virtual currency can be used as another alternative of payment along with the guideline provided and explained in number of fatwa above. However, the rule of the fatwa can apply in areas that have used virtual currency legally and have been recognized by the country concerned. Whereas at present, the fatwa cannot be applied in Indonesia because it has no legitimacy from the government.

After going through the analysis, the authors conclude that transaction that occurs in Inacoin trading are legal but unlawful. This is because Inacoin has fulfilled the pillars and requirements 
of the al-sarf but violates some elements that are prohibited by Islam such as the existence of gharar, speculation and fear of the occurrence of harm to the user.

\section{CONCLUSION AND SUGGESTION}

\section{Conclusions}

1. Based on our analysis, Inacoin cannot be called as a currency because it does not meet the requirements or criteria of money. In addition to that, the function of Inacoin is also not in accordance with the function of money in Islam because Inacoin is more dominant as a commodity traded, not as a medium of exchange. Besides, we found no law that explicitly allows the circulation of Inacoin.

2. Transactions that occur in the sale and purchase of Inacoin are legal but unlawful. This is because Inacoin has fulfilled the pillars and conditions of the al-sarf but violates some elements that are prohibited by Islam such as the existence of gharar, speculation and fear of the occurrence of harm to the user.

\section{Suggestions}

1. Regulations regarding virtual currency in Indonesia are still not detailed and firm. Bank Indonesia only said that the virtual currency in Indonesia is not valid. However, there is no strict regulation regarding punishment to follow up the statement that using a virtual currency is really in violation of law. For this reason, it is expected that Bank Indonesia can make regulations regarding the use of virtual currency in Indonesia in more detail. In addition to that, there is a need for synchronization between BI, OJK, and BAPPEBTI so that the community will not be confused about which regulation prevails as to avoid the room for bias regulation.

2. For people who recently get to know about Inacoin and want to use Inacoin as a tool for doing business, it is expected that they must be careful. This is because there is no guarantee or protection for the loss of Inacoin. When a person or company that owns Inacoin is stored in a virtual wallet on a 
PC or smartphone, then a virus or hack can cause Inacoin to disappear.

3. For the next researcher, the author realizes that there are still many limitations in this study. Thus, the authors suggest next researcher to re-examine the conclusion provided when the circumstances change along with the development of Inacoin. In addition, the authors also suggest next researcher to examine whether the vitual currency can be said to be equivalent if exchanged for fiat currencies.

\section{BIBLIOGRAPHY}

Al-Mundziri. (2002). Mukhtasar Shahih Muslim, Diterjemahkan oleh Syinqithy Djamaluddin dan Mochtar Zoerni. Ringkasan Shahih Muslim. Bandung: Mizan.

Ascarya. 2012. Akad dan Produk Bank Syariah. Jakarta: PT RajaGrafindo Persada.

Che Ludin, Che Mohd Fakhri dkk. t.th (2014)."Bitcoin: Analisis Bitcoin Melalui Muamalat dan Maslahat." Ijtihad dalam Isu-Isu Sains dan Pemikiran Saintifik. Malaysia: Universiti Malaya.

Fajar ND, M \& Achmad, Y. (2015). Dualisme penelitian hukum: normatif \& empiris. Yogyakarta: Pustaka Pelajar.

Hasan, A. (2004). Al-Auraq al-Naqdiyah fi al-Iqtishad al-Islamy, Diterjemahkan oleh Saifurrahman Barito dan Zulfakar Ali. 2005. Mata Uang Islami: Telaah Komprehensif Sistem Keuangan Islami. Jakarta: PT Raja Grafindo.

Inacoin. (2018). "Inacoin White Paper". Jakarta: PT. Indoco Sosusi Pratama.

ISRA. (2015). Sistem Keuangan Islam Prinsip \& Operasi. Jakarta : PT Raja Grafindo Persada.

Karim, A. A. (2007). Ekonomi Makro Islam. Jakarta: PT RajaGrafindo Persada.

Kasmir. (2002). Bank dan Lembaga Keuangan Lainnya. Jakarta: PT Raja Grafindo.

Marzuki, P. M. (2017). Penelitian Hukum. Jakarta: Kencana. 
Mulyanto, F. (2015). Pemanfaatan Cryptocurrency Sebagai Penerapan Mata Uang Rupiah Kedalam Bentuk Digital Menggunakan Teknologi Bitcoin. IJNS-Indonesian Journal on Networking and Security, 4(4).

Murni, A. (2006). Ekonomika Makro, Cet. I. Bandung: Refika Aditama.

Sholihah, N. L. (2014). Tinjauan fiqih muamalah terhadap uang digital bitcoin dengan studi pada DSN-MUI dan perusahaan artabit. Bachelor Dissertation: UIN Syarif Hidayatullah.

Sujarweni, V. W. (2014). Metodologi Penelitian. Yogyakarta: Pustaka Baru.

Sugiyono. (2010). Metode Penelitian Administrasi, Bandung: Alfabeta

Wijaya, D. A. (2018). Bitcoin Mining: Dan Cryptocurrency Lainnya. Jasakom.

Yusuf, A. M. (2014). Metode Penelitian Kuantitatif, Kualitatif, dan penelitian Gabungan. Jakarta: Prenadamedia Group. 